\title{
Local application of tranexamic acid affects tendon healing negatively in the late period
}

\author{
Traneksamik asidin lokal uygulanması geç dönemde \\ tendon iyileşmesini olumsuz etkilemektedir
}

\author{
Alper Çıraklı, MD, ${ }^{1}$ Pınar Naile Gürgör, PhD, ${ }^{2}$ Erdal Uzun, MD, ${ }^{3}$ Havva Erdem, MD, ${ }^{4}$ \\ Soner Çankaya, $\mathrm{PhD},{ }^{5}$ Orhan Baş, $\mathrm{PhD}^{6}$ \\ 'Department of Orthopedics and Traumatology, Medical Faculty of Ordu University, Ordu, Turkey \\ ${ }^{2}$ Department of Histology and Embryology, Medical Faculty of Ordu University, Ordu, Turkey \\ ${ }^{3}$ Department of Orthopedics and Traumatology, Kayseri Training and Research Hospital, Kayseri, Turkey \\ ${ }^{4}$ Department of Pathology, Medical Faculty of Ordu University, Ordu, Turkey \\ ${ }^{5}$ Department of Biostatistics, Medical Faculty of Ordu University, Ordu, Turkey \\ ${ }^{6}$ Department of Anatomy, Medical Faculty of Ordu University, Ordu, Turkey
}

\begin{abstract}
Objectives: This study aims to evaluate the potential adverse effects of tranexamic acid (TA) on tendon healing.

Materials and methods: Twelve male Wistar-Albino rats (weighing $300 \mathrm{~g}$ to $350 \mathrm{~g}$ ) were used in the study. Rats were divided into two groups. Right legs of the rats were determined as the TA group and left legs as the serum physiologic (SP) group. Bilateral Achilles tenotomy was performed and surgically repaired. For the right side, $1 \mathrm{~mL}$ of TA and for the left side, $1 \mathrm{~mL}$ of SP were applied. Half of the rats were sacrificed at the third week and the other half at the sixth week and tendon samples were collected from the extremities. Histological analyses were performed according to the tendon scoring system (Bonar classification).
\end{abstract}

Results: Tenocyte cell morphology was better in the third week in TA group than in SP group. In terms of colloidal organization, SP groups gave superior results in all weeks. An analysis of total tendon healing scores revealed that the results of the third week TA groups were superior to the results of the sixth week TA groups. Tenocyte morphology and total tendon healing scores of rats in the sixth week TA group were statistically significantly lower compared to the third week TA group (tenocyte morphology $\mathrm{p}=0.009$, total score $\mathrm{p}=0.041$ ).

Conclusion: In this study, we detected that locally administered TA has an adverse effect on tendon healing in late period. However, further immunohistochemical and biomechanical studies are needed to support these results.

Keywords: Bleeding, hemostasis, injury, recovery, tendon, tranexamic acid.

\section{ÖZ}

Amaç: $\mathrm{Bu}$ çalışmada traneksamik asidin (TA) tendon iyileşmesindeki potansiyel olumsuz etkileri değerlendirildi.

Gereç ve yöntemler: Çalışmada 12 erkek Wistar-Albino sıçan (ağırlık 300 g - 350 g) kullanıldı. Sıçanlar iki gruba ayrıldı. Sıçanların sağ bacakları TA grubu, sol bacakları serum fizyolojik (SF) grubu olarak belirlendi. İki taraflı Aşil tenotomisi yapıldı ve cerrahi olarak tamir edildi. Sağ taraf için $1 \mathrm{~mL}$ TA, sol taraf için $1 \mathrm{~mL}$ SF uygulandı. Sıçanların yarısı üçüncü haftada, diğer yarısı altıncı haftada sakrifiye edildi ve ekstremitelerden tendon örnekleri alındı. Histopatolojik analizler tendon skorlama sistemine (Bonar sinıflaması) göre yapıldı.

Bulgular: Üçüncü haftada tenosit hücre morfolojisi TA grubunda SF grubundan daha iyi idi. Kolloidal organizasyon açısından, SF grupları bütün haftalarda daha üstün sonuçlar verdi. Toplam tendon iyileşme skorları incelendiğinde, üçüncü hafta TA gruplarının sonuçlarının altıncı hafta TA gruplarının sonuçlarından daha üstün olduğu görüldü. Altıncı hafta TA grubundaki sıçanların tenosit morfolojisi ve toplam tendon iyileşme skorları üçüncü hafta TA grubuna göre istatistiksel olarak anlamlı şekilde daha düşük idi (tenosit morfolojisi $\mathrm{p}=0.009$, toplam skor $\mathrm{p}=0.041$ ).

Sonuç: Bu çalışmada lokal uygulanan TA'nın geç dönemde tendon iyileşmesi üzerinde olumsuz etkisi olduğu tespit edildi. Ancak bu sonuçları desteklemek için ileri immünohistokimyasal ve biyomekanik çalışmalara gereksinim vardır.

Anahtar sözcükler: Kanama, hemostaz, yaralanma, iyileşme, tendon, traneksamik asit.

- Received: June 02, 2017 Accepted: October 17, 2017

- Correspondence: Erdal Uzun, MD. Kayseri Eğitim ve Araștırma Hastanesi Ortopedi ve Travmatoloji Kliniği, 38010 Kocasinan, Kayseri, Istanbul, Turkey. Tel: +90 507 - 2117999 e-mail: nuzuladre@gmail.com 
Total number of knee arthroplasty operations is increasing. Blood loss, long hospital stay, postoperative morbidity and delay in postoperative rehabilitation are well known complications of this procedure..$^{[1]}$ There are studies in the literature with hemostatic agents and researches are still ongoing. Antifibrinolytic drugs such as tranexamic acid (TA) have been used in elective orthopedic surgeries to reduce bleeding and blood transfusions perioperatively. ${ }^{[2]}$ Although there is a consensus on this positive effect of TA, it is not known what kind of effect TA has on the surrounding tissues, especially when applied to quadriceps.

Tranexamic acid is used intravenously (IV) and orally for the purpose of stopping excessive bleeding or facilitating clotting in emergency services and postoperatively. Topical use was recognized by the use of otolaryngology doctors. In the field of orthopedics and traumatology, intraarticular use was found to reduce bleeding and consequently blood transfusion in the perioperative period. ${ }^{[2,3]}$ Scientific demonstration of the effect of TA on tendons as well as the positive effect of TA on local bleeding with multiple tendon injuries and local application during joint surgery involving many tendons will contribute to the literature on the use of this material, which has been used frequently in recent years. However, to our knowledge, there is no study about the effect of local application of TA on tendon healing. This study was performed using the well-known rat tendon injury model..$^{[1,4]}$ In this study, we aimed to evaluate the potential adverse effects of TA on tendon healing.

\section{MATERIALS AND METHODS}

The study was conducted at Ondokuz Mayis University between November 2016 and May 2017 with the approval of the local Ethics Committee (Ordu University) of experimental animals (dated 12.05.2016, number 4/decision 8). The study was conducted in accordance with the principles of Care and Use of the Laboratory Animals and the animal rights were protected. Twelve male Wistar-Albino rats (weighing $300 \mathrm{~g}$ to $350 \mathrm{~g}$ ) were divided into two groups so that the weights of the animals were close to each other. The right legs of the rats were determined as the TA group and the left legs as the serum physiologic (SP) group. Half of the rats were
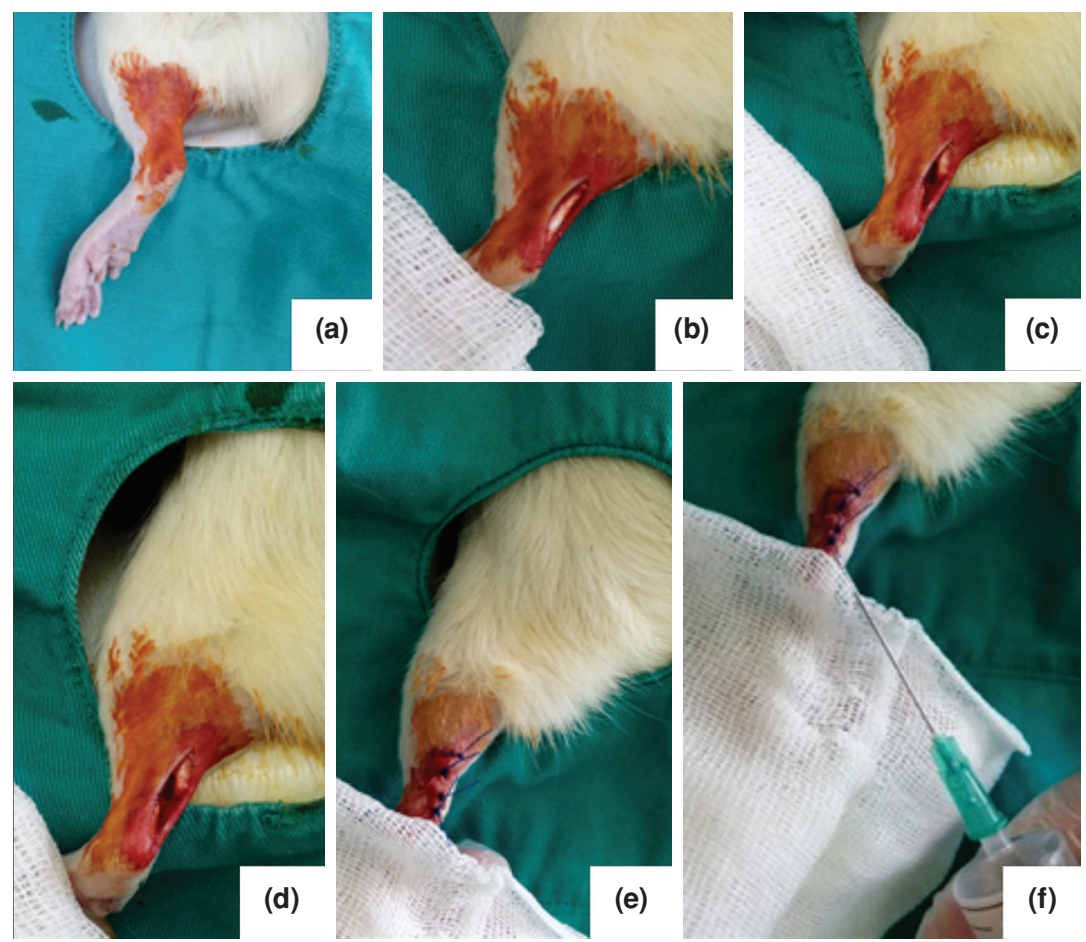

Figure 1. (a) Animals were shaved and disinfected with polyvinylpyrrolidone-iodine, (b) and covered with sterile compresses. (c) Skin and subcutaneous tissues were passed through incisions of Achilles tendons with no. 11 scalpels at approximately $0.5 \mathrm{~cm}$ proximal to insertion to calcaneus. (d) All tendons were repaired with 4/0 polypropylene suture using a modified Kessler-type technique. (e) Incisions were closed using 2.0 polypropylene suture. (f) $1 \mathrm{~mL}$ of tranexamic acid was applied to right leg and $1 \mathrm{~mL}$ isotonic serum physiologic was applied to left leg locally. 

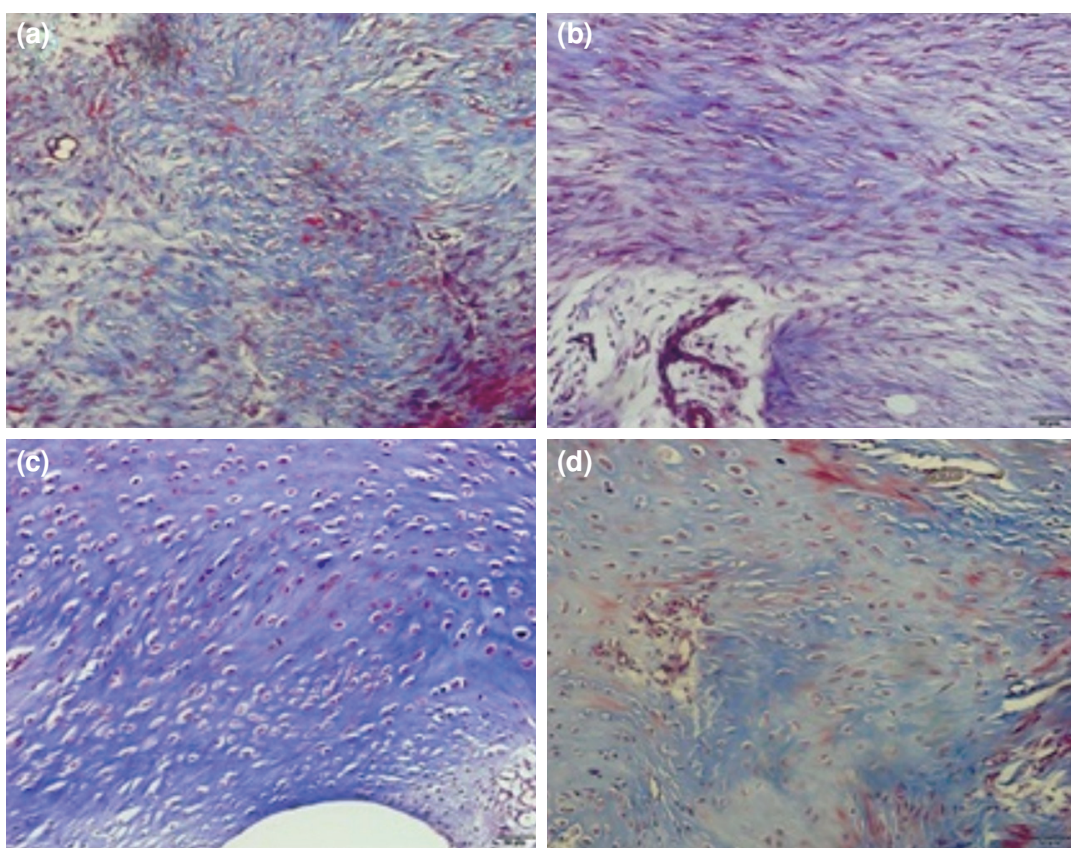

Figure 2. Tenocyte cell morphologies (Masson's trichrome stain, $\times 200$ magnification) by week and application groups. (a) Significantly rounded tenocytes in SP3 group. (b) Roots and rounded tenocytes in TA3 group. (c) Significant chondroid changes in tendon in SP6 group. (d) Chondroid change in TA6 group.

sacrificed at the third week (right leg-TA3, left leg-SP3) and the other half at sixth week (right leg-TA6, left leg-SP6) and tendon samples were collected from the extremities. The reason for taking the samples at third and sixth weeks of the study was to determine the effect of TA on hemostasis-inflammation, which is the first phase of healing, and subsequent proliferationangiogenesis phases.
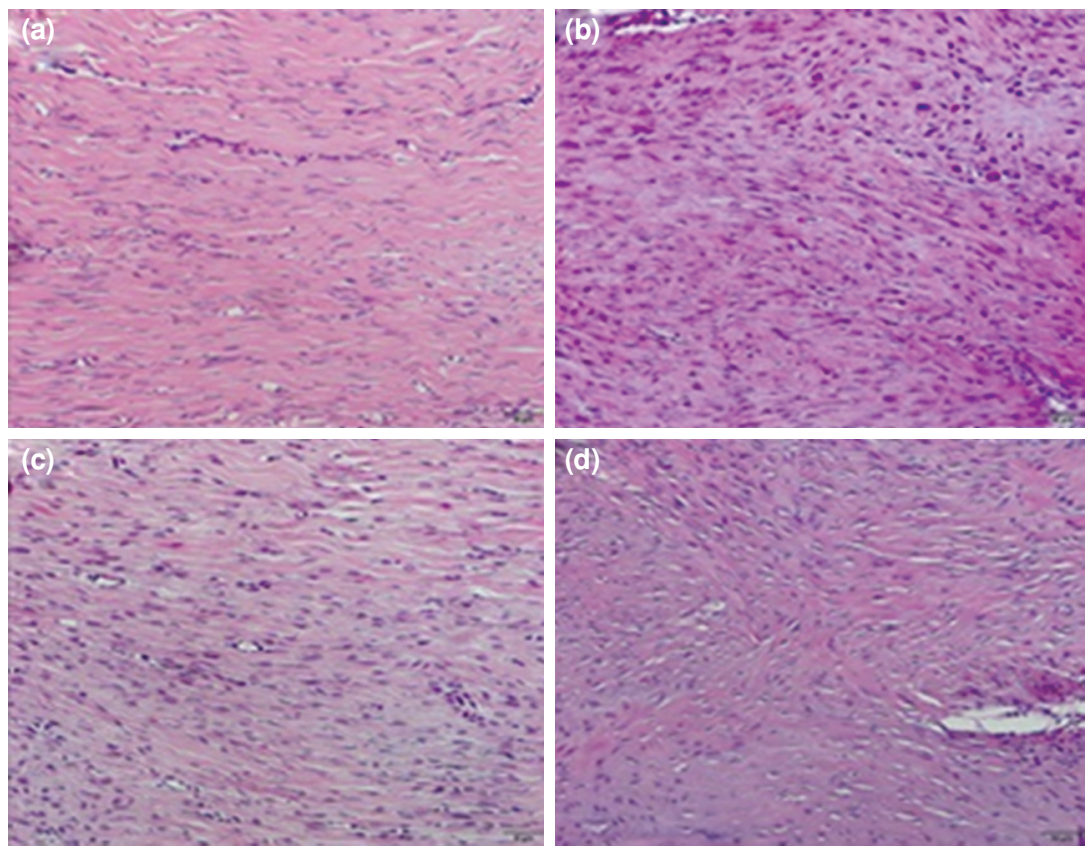

Figure 3. Tendon collagen regulation by week and application groups $(\mathrm{H}-\mathrm{E} \times 200)$.

$(a, c)$ More regular collagen organization in serum physiologic groups. (b, d) Irregular collagen organization in tranexamic acid groups. 
Operations were conducted under general anesthesia with intraperitoneal injection of ketamine $90 \mathrm{mg} / \mathrm{kg}$ (Ketalar; Eczacıbaşı, Istanbul, Turkey) and xylazine hydrochloride $3 \mathrm{mg} / \mathrm{kg}$ (Rompun; Bayer, Leverkusen, Germany). After appropriate anesthetic conditions, animals were shaved with care to avoid damaging the skin with a razor blade and disinfected with polyvinylpyrrolidone-iodine (Batticon ${ }^{\odot}$, Adeka, Samsun, Turkey) (Figure 1a). The surgical field was covered with sterile compresses (Figure 1b). Skin and subcutaneous tissues were passed through the incisions of the right and left Achilles tendons with a $3 \mathrm{~cm}$ incision (Figure 1c). Bilateral Achilles tendons were tenotomized with no. 11 scalpels at approximately $0.5 \mathrm{~cm}$ proximal to the insertion to the calcaneus (Figure 1d). All tendons were repaired with 4/0 polypropylene suture (Propilen; Doğsan Tibbi Malzeme San A.Ş, Trabzon, Turkey) using a modified Kessler-type technique (Figure 1e). The surgical wounds were closed primarily with $3 / 0$ polypropylene skin sutures (Propilen, Doğsan Tibbi Malzeme San A.Ş, Trabzon, Turkey). On surgical sites, $1 \mathrm{~mL}$ of TA (Transamine $250 \mathrm{mg} / 5 \mathrm{~mL}$, Actavis Pharma Inc., Istanbul, Turkey) was applied to the right leg and $1 \mathrm{~mL}$ isotonic SP was applied to the left leg locally (Figure 1f).

Wound dressing was performed. During the experiment, rats were kept at normal room temperature and humidity by feeding with standard pellet feed and tap water for 10/14 hours in a light/dark cycle of light, three subjects per cage. After the surgical procedure, all animals were regularly treated with wound dressing. At third and sixth weeks, the rats were sacrificed.

All tendons were removed with the bone tissue adjacent exposing suture area and fixed with $10 \%$ buffered formaldehyde solution. Then, the samples were decalcified in 10\% formic acid solution, histological tissue monitoring was performed and paraffin tissue blocks were prepared. Sections with a thickness of $5 \mu \mathrm{m}$ were taken longitudinally from the blotted tissues. Hematoxylin and eosin, and Masson's trichrome and alcian blue staining were performed

TABLE I

Serum physiologic and tranexamic acid values measured in terms of groups

\begin{tabular}{|c|c|c|c|c|c|}
\hline Groups & Mean $\pm S D$ & Median & IQR & Min-Max & $p$ \\
\hline \multicolumn{6}{|l|}{ Tenocytes 200x } \\
\hline Serum physiologic 3 & $1.833 \pm 0.983$ & 1.50 & 2.00 & $1.00-3.00$ & \multirow{2}{*}{0.310} \\
\hline Tranexamic acid 3 & $1.167 \pm 0.408$ & 1.00 & 0.25 & $1.00-2.00$ & \\
\hline Serum physiologic 6 & $2.500 \pm 0.548$ & 2.50 & 1.00 & $2.00-3.00$ & \multirow{2}{*}{0.394} \\
\hline Tranexamic acid 6 & $2.167 \pm 0.408$ & 2.00 & 0.25 & $2.00-3.00$ & \\
\hline \multicolumn{6}{|l|}{ Basic substance $100 x$} \\
\hline Serum physiologic 3 & $2.000 \pm 0.000$ & 2.00 & 0.00 & $2.00-2.00$ & \multirow{2}{*}{0.699} \\
\hline Tranexamic acid 3 & $1.833 \pm 0.408$ & 2.00 & 0.25 & $1.00-2.00$ & \\
\hline Serum physiologic 6 & $2.000 \pm 0.000$ & 2.00 & 0.00 & $2.00-2.00$ & \multirow{2}{*}{1.000} \\
\hline Tranexamic acid 6 & $2.000 \pm 0.000$ & 2.00 & 0.00 & $2.00-2.00$ & \\
\hline \multicolumn{6}{|l|}{ Collagen $100 x$} \\
\hline Serum physiologic 3 & $1.167 \pm 0.408$ & 1.00 & 0.25 & $1.00-2.00$ & \multirow{2}{*}{0.132} \\
\hline Tranexamic acid 3 & $1.833 \pm 0.753$ & 2.00 & 1.25 & $1.00-3.00$ & \\
\hline Serum physiologic 6 & $1.667 \pm 0.516$ & 2.00 & 1.00 & $1.00-2.00$ & \multirow{2}{*}{0.240} \\
\hline Tranexamic acid 6 & $2.167 \pm 0.408$ & 2.00 & 0.25 & $2.00-3.00$ & \\
\hline \multicolumn{6}{|l|}{ Vascularity $400 \times$} \\
\hline Serum physiologic 3 & $3.000 \pm 0.000$ & 3.00 & 0.00 & $3.00-3.00$ & \multirow{2}{*}{1.000} \\
\hline Tranexamic acid 3 & $3.000 \pm 0.000$ & 3.00 & 0.00 & $3.00-3.00$ & \\
\hline Serum physiologic 6 & $3.000 \pm 0.000$ & 3.00 & 0.00 & $3.00-3.00$ & \multirow{2}{*}{1.000} \\
\hline Tranexamic acid 6 & $3.000 \pm 0.000$ & 3.00 & 0.00 & $3.00-3.00$ & \\
\hline \multicolumn{6}{|l|}{ Total scores } \\
\hline Serum physiologic 3 & $8.000 \pm 1.265$ & 7.50 & 2.25 & $7.00-10.00$ & \multirow{2}{*}{0.937} \\
\hline Tranexamic acid 3 & $7.833 \pm 1.169$ & 7.50 & 1.50 & $7.00-10.00$ & \\
\hline Serum physiologic 6 & $9.167 \pm 0.753$ & 9.00 & 1.25 & $8.00-10.00$ & \multirow{2}{*}{0.818} \\
\hline Tranexamic acid 6 & $9.333 \pm 0.516$ & 9.00 & 1.00 & $9.00-10.00$ & \\
\hline
\end{tabular}

SD: Standard deviation; IQR: Interquartile range (Q3-Q1); Min: Minimum; Max: Maximum. 
and histopathological evaluation was implemented. The specimens separated into four groups were examined objectively by an expert histologist and pathologist. Preparations were examined under a BX-53 model Olympus microscope (Olympus Corporation, Tokyo, Japan) and the necessary images were recorded (Figures 2 and 3). The samples were evaluated using the Bonar classification, a semiquantitative tendon scoring method..$^{[5]}$ Bonar classification consists of tenocyte morphology, degree of ground substance staining, collagen morphology, and vascularity parameters. Each parameter is evaluated between 0 and 3 points. Total tendon healing scores indicate that all parameters are evaluated together. In this classification, low scores indicate good tendon healing, whereas high scores indicate bad tendon healing.

\section{Statistical analysis}

The data (total tendon healing scores) were firstly analyzed using Levene's test and the ShapiroWilk test for equality of variance and normality assumption, respectively $(\mathrm{p}<0.05)$. Secondly, the differences between the TA and SP groups were analyzed by using Mann-Whitney $\mathrm{U}$ test. According to the results of this test, the data for SP3 and TA3, SP6 and TA6, SP3 and SF6, TA3 and TA6, respectively, were expressed as sample size, mean with standard deviation, median, interquartile range and minimum and maximum values. The results were accepted as significant at the level of $\mathrm{p}<0.05$. All the statistical calculations were performed with the IBM SPSS version 22.0 (IBM Corp., Armonk, NY, USA) statistical program.

\section{RESULTS}

An examination of the Bonar classification parameters revealed that tenocyte cell morphology was better in the TA group than SP group at the third week. In terms of colloidal organization, SP groups gave superior results in all terms. An examination of the total tendon healing scores showed that the results were superior at the third week than at the sixth week in all groups.

\section{TABLE II}

Serum physiologic and tranexamic acid values measured in terms of weeks

\begin{tabular}{|c|c|c|c|c|c|}
\hline Groups & Mean $\pm S D$ & Median & IQR & Min-Max & $p$ \\
\hline \multicolumn{6}{|l|}{ Tenocytes 200x } \\
\hline Serum physiologic 3 & $1.833 \pm 0.983$ & 1.50 & 2.00 & $1.00-3.00$ & \multirow{2}{*}{0.240} \\
\hline Serum physiologic 6 & $2.500 \pm 0.548$ & 2.50 & 1.00 & $2.00-3.00$ & \\
\hline Tranexamic acid 3 & $1.167 \pm 0.408$ & 1.00 & 0.25 & $1.00-2.00$ & \multirow{2}{*}{0.009} \\
\hline Tranexamic acid 6 & $2.167 \pm 0.408$ & 2.00 & 0.25 & $2.00-3.00$ & \\
\hline \multicolumn{6}{|l|}{ Basic substance $100 x$} \\
\hline Serum physiologic 3 & $2.000 \pm 0.000$ & 2.00 & 0.00 & $2.00-2.00$ & \multirow{2}{*}{1.000} \\
\hline Serum physiologic 6 & $2.000 \pm 0.000$ & 2.00 & 0.00 & $2.00-2.00$ & \\
\hline Tranexamic acid 3 & $1.833 \pm 0.408$ & 2.00 & 0.25 & $1.00-2.00$ & \multirow{2}{*}{0.699} \\
\hline Tranexamic acid 6 & $2.000 \pm 0.000$ & 2.00 & 0.00 & $2.00-2.00$ & \\
\hline \multicolumn{6}{|l|}{ Collagen $100 x$} \\
\hline Serum physiologic 3 & $1.167 \pm 0.408$ & 1.00 & 0.25 & $1.00-2.00$ & \multirow{2}{*}{0.180} \\
\hline Serum physiologic 6 & $1.667 \pm 0.516$ & 2.00 & 1.00 & $1.00-2.00$ & \\
\hline Tranexamic acid 3 & $1.833 \pm 0.753$ & 2.00 & 1.25 & $1.00-3.00$ & \multirow{2}{*}{0.485} \\
\hline Tranexamic acid 6 & $2.167 \pm 0.408$ & 2.00 & 0.25 & $2.00-3.00$ & \\
\hline \multicolumn{6}{|l|}{ Vascularity $400 \times$} \\
\hline Serum physiologic 3 & $3.000 \pm 0.000$ & 3.00 & 0.00 & $3.00-3.00$ & \multirow{2}{*}{1.000} \\
\hline Serum physiologic 6 & $3.000 \pm 0.000$ & 3.00 & 0.00 & $3.00-3.00$ & \\
\hline Tranexamic acid 3 & $3.000 \pm 0.000$ & 3.00 & 0.00 & $3.00-3.00$ & \multirow{2}{*}{1.000} \\
\hline Tranexamic acid 6 & $3.000 \pm 0.000$ & 3.00 & 0.00 & $3.00-3.00$ & \\
\hline \multicolumn{6}{|l|}{ Total scores } \\
\hline Serum physiologic 3 & $8.000 \pm 1.265$ & 7.50 & 2.25 & $7.00-10.00$ & \multirow{2}{*}{0.132} \\
\hline Serum physiologic 6 & $9.167 \pm 0.753$ & 9.00 & 1.25 & $8.00-10.00$ & \\
\hline Tranexamic acid 3 & $7.833 \pm 1.169$ & 7.50 & 1.50 & $7.00-10.00$ & \multirow{2}{*}{0.041} \\
\hline Tranexamic acid 6 & $9.333 \pm 0.516$ & 9.00 & 1.00 & $9.00-10.00$ & \\
\hline
\end{tabular}

SD: Standard deviation; IQR: Interquartile range (Q3-Q1); Min: Minimum; Max: Maximum. 
Tenocyte morphology and tendon healing scores of TA6 group gave significantly inferior results when compared to TA3 group (tenocyte morphology $p=0.009$, total score $=0.041$ ). Other results according to Bonar classification were summarized in Tables 1 and 2.

\section{DISCUSSION}

The most important finding obtained in this study was that local application of TA had negative effect on tendon healing in the late period. TA is thought to cause this situation by reducing angiogenesis in the initial phase of healing and formation of hematoma in the progressive phase. There is a consensus at the point that TA, which is frequently used in the current practice of orthopedics, reduces blood transfusion by reducing bleeding. ${ }^{[6]}$ However, the lack of information on the effect of this agent on neighboring tissues makes this study remarkable in terms of creating awareness about its use.

Tranexamic acid has been previously used quite successfully in urological, gynecological, and thoracic surgical procedures to reduce postoperative blood loss. ${ }^{[7]}$ The first use in orthopedic surgery was performed in 1997 by Akuzi et al., ${ }^{[8]}$ who reported that they did not transfuse blood after 42 bilateral and 64 unilateral knee prostheses. Also, Konig et al. ${ }^{[9]}$ first reported that they reduced transfusion rates. In their meta-analysis, Zufferey et al. ${ }^{[10]}$ defined that TA reduced blood loss in major orthopedic surgeries. In accordance with this, Aydin et al ${ }^{[1]}$ reported that use of TA decreased the duration of hospital stay after surgery and total hospital costs.

Tranexamic acid can be administered intramuscularly, orally, IV or locally..$^{[1]}$ There are a number of studies in the literature concerning the perioperative use of TA in joint surgery for localized use of TA, ease of administration, maximum concentration on bleeding site, and reduced systemic risks due to low drug absorption. ${ }^{[7]}$ In some studies, it has been shown that local administration is more effective than placebo and other administration methods. ${ }^{[6,7,12-14]}$ Although the positive effects of TA are known, the chemical effect of the intraarticular application on the surrounding soft tissue is not known clearly. ${ }^{[6]}$ There is no consensus on the amount and method of local application of TA. ${ }^{[12,15]}$ In recent studies related with joints, $2 \mathrm{~g}$ intraarticular administration of TA was more effective than other doses. ${ }^{[16]}$ There are different methods of intraarticular application, such as applying the drug into the joint after wound closure, washing the joint with drug before wound closure, and injecting the drug into the joint through drain. ${ }^{[12,16-19]}$ In this study, $1 \mathrm{~mL}$ TA was applied with an injector to allow its accumulation directly in the soft tissue in the wound after the skin was covered.

A limited number of studies with hemostatic agents are available in the literature. Similar to our findings, Aydin et al ${ }^{[1]}$ found significantly worse total tendon healing scores in their study with Ankaferd BloodStopper ${ }^{\circledR}$ (Ankaferd İstanbul İlaç ve Sağlık Ürünleri AŞ, Istanbul, Turkey) in the TA group than in the SP group. Whereas He et al. ${ }^{[20]}$ reported that the use of fibrin glue for flexor tendon repair in rabbit models improved adhesion in early period so it can be safely used for regeneration and healing purposes on this site. In this study, according to Bonar classification, total tendon healing scores in all third week groups were significantly superior when compared to all sixth week groups.

A study on fibroblast culture model compared three hemostatic agents (Ankaferd, fibrin glue, and TA) in terms of their effects on healing, and showed that all agents had negative effects on fibroblasts, with Ankaferd having the lowest values of cell proliferation, cell number, and viability. ${ }^{[21]}$ Okumuş et al. ${ }^{[22]}$ reported that Ankaferd did not lead to any degeneration of regional tissue and systemic tissues. In another study, Ankaferd had a significantly negative effect on colloid organization. ${ }^{[1]}$ However, Cancan et al. ${ }^{[23]}$ showed that topical Ankaferd had a positive effect on angiogenesis and improved colloid organization. In this study, although the tenocyte cell morphology in the third week TA group was better than the SP group, the SP groups in all weeks gave superior results in terms of colloid organization. Similar results were obtained in all groups in terms of basic substance and vasculancy.

In this study, an evaluation of the samples obtained in third and sixth weeks according to Bonar classification revealed that the healing score observed in the tendons in the third week was superior to that of the sixth week. Also, an analysis of the TA group showed that the tenocytes had more round nuclei and greater amount of cytoplasm in the third week. However, in the sixth week, we detected that the tenocyte nuclei became round more specifically, the cytoplasm increased, and areas of chondroid metaplasia formed locally. This condition may indicate that tendon healing in the third week was better compared to the sixth week. In tendon healing, a low mean of total scoring is preferred. However, the means of total scoring in TA and SP groups were found to be high, which led us to interpret that TA may be affecting tendon healing negatively in the late period. This effect may have resulted from the used dosage, and administration method. 
There are some limitations of this study. First is the lack of biomechanical analyses. Although histological evaluation is important for tendon healing process, biomechanical test results are also important for the evaluation of tendon repairs. A second limitation is the lack of markers about immunohistochemical evaluation. Lastly, the applied TA in this study, which may have resulted in a pure and nonhomogeneous application into tissues unlike clinical applications, may have caused study-clinical incompatibility.

In conclusion, the results of this study showed a late adverse effect of local TA on tendon healing. TA may cause delayed healing by reducing hemorrhage and adversely affecting the healing phases of hemostasisinflammation and proliferation-angiogenesis. This might lead to clinically weak-late recovery, inadequatelate rehabilitation and delayed return to social life and work. The results of this study may bring a new perspective on the use of TA at orthopedic and other surgical procedures. Further studies including biomechanical and immunohistochemical studies are needed to investigate the effects of TA application on tendon healing.

\section{Declaration of conflicting interests}

The authors declared no conflicts of interest with respect to the authorship and/or publication of this article.

\section{Funding}

The authors received no financial support for the research and/or authorship of this article.

\section{REFERENCES}

1. Aydın BK, Altan E, Acar MA, Erkoçak ÖF, Ugraş S. Effect of Ankaferd blood stopper ${ }^{\circledR}$ on tendon healing: an experimental study in a rat model of Achilles tendon injury. Eklem Hastalik Cerrahisi 2015;26:31-7.

2. Atik OS. Does tranexamic acid reduce blood loss and blood transfusion requirement in knee arthroplasty? Eklem Hastalik Cerrahisi 2012;23:166-7.

3. Seo JG, Moon YW, Park SH, Kim SM, Ko KR. The comparative efficacies of intra-articular and IV tranexamic acid for reducing blood loss during total knee arthroplasty. Knee Surg Sports Traumatol Arthrosc 2013;21:1869-74.

4. Ozer H, Taşkesen A, Kul O, Selek HY, Turanlı S, Köse K. Effect of glucosamine chondroitine sulphate on repaired tenotomized rat Achilles tendons. [Article in Turkish] Eklem Hastalik Cerrahisi 2011;22:100-6.

5. Cook JL, Feller JA, Bonar SF, Khan KM. Abnormal tenocyte morphology is more prevalent than collagen disruption in asymptomatic athletes' patellar tendons. J Orthop Res 2004;22:334-8.

6. Aydın BK, Durgut F, Erkoçak ÖF, Acar MA. Other benefits of intra-articular injection of tranexamic acid in primary total knee arthroplasty apart from reducing blood transfusion rates. Eklem Hastalik Cerrahisi 2017;28:25-9.

7. Békássy Z, Astedt B. Treatment with the fibrinolytic inhibitor tranexamic acid--risk for thrombosis? Acta Obstet Gynecol Scand 1990;69:353-4.

8. Akizuki S, Yasukawa Y, Takizawa T. A new method of hemostasis for cementless total knee arthroplasty. Bull Hosp Jt Dis 1997;56:222-4.

9. Konig G, Hamlin BR, Waters JH. Topical tranexamic acid reduces blood loss and transfusion rates in total hip an total knee arthroplasty. J Arthroplasty 2013;28:1473-6.

10. Zufferey P, Merquiol F, Laporte S, Decousus H, Mismetti $\mathrm{P}$, Auboyer $\mathrm{C}$, et al. Do antifibrinolytics reduce allogeneic blood transfusion in orthopedic surgery? Anesthesiology 2006;105:1034-46.

11. Karaaslan F, Karaoğlu S, Mermerkaya MU, Baktir A. Reducing blood loss in simultaneous bilateral total knee arthroplasty: combined intravenous-intra-articular tranexamic acid administration. A prospective randomized controlled trial. Knee 2015;22:131-5.

12. Çavuşoğlu AT, Ayanoğlu T, Esen E, Atalar H, Turanlı S. Is intraarticular administration of tranexamic acid efficient and safe as systemic administration in total knee arthroplasty? Single center, randomized, controlled trial. [Article in Turkish] Eklem Hastalik Cerrahisi 2015;26:164-7.

13. Yang Y, Lv YM, Ding PJ, Li J, Ying-Ze Z. The reduction in blood loss with intra-articular injection of tranexamic acid in unilateral total knee arthroplasty without operative drains: a randomized controlled trial. Eur J Orthop Surg Traumatol 2015;25:135-9.

14. Wang $\mathrm{H}$, Shen $\mathrm{B}$, Zeng $\mathrm{Y}$. Comparison of topical versus intravenous tranexamic acid in primary total knee arthroplasty: a meta-analysis of randomized controlled and prospective cohort trials. Knee 2014;21:987-93.

15. Patel JN, Spanyer JM, Smith LS, Huang J, Yakkanti MR, Malkani AL. Comparison of intravenous versus topical tranexamic acid in total knee arthroplasty: a prospective randomized study. J Arthroplasty 2014;29:1528-31.

16. Zhang H, Chen J, Chen F, Que W. Zhang H, Chen J, Chen F, Que $\mathrm{W}$. The effect of tranexamic acid on blood loss and use of blood products in total knee arthroplasty: a meta-analysis. Knee Surg Sports Traumatol Arthrosc 2012;20:1742-52.

17. Aguilera X, Martinez-Zapata MJ, Bosch A, Urrútia G, González JC, Jordan $M$, et al. Efficacy and safety of fibrin glue and tranexamic acid to prevent postoperative blood loss in total knee arthroplasty: a randomized controlled clinical trial. J Bone Joint Surg [Am] 2013;95:2001-7.

18. Mutsuzaki H, Ikeda K. Intra-articular injection of tranexamic acid via a drain plus drain-clamping to reduce blood loss in cementless total knee arthroplasty. J Orthop Surg Res 2012;7:32.

19. Gomez-Barrena E, Ortega-Andreu M, Padilla-Eguiluz NG, Pérez-Chrzanowska H, Figueredo-Zalve R. Topical intraarticular compared with intravenous tranexamic acid to reduce blood loss in primary total knee replacement: a double-blind, randomized, controlled, noninferiority clinical trial. J Bone Joint Surg [Am] 2014;96:1937-44.

20. He M, Gan AW, Lim AY, Goh JC, Hui JH, Lee EH, et al. The effect of fibrin glue on tendon healing and adhesion formation in a rabbit model of flexor tendon injury and repair. J Plast Surg Hand Surg 2013;47:509-12.

21. Emes Y, Aybar B, Vural P, Işsever H, Yalçn S, Atalay B, et al. Effects of hemostatic agents on fibroblast cells. Implant Dent 2014;23:641-7.

22. Okumuş M, Yüksel KZ, Özbağ D, Çıralık H, Yılmaz Z, Gümüşalan $Y$, et al. Medicinal plant extract (Ankaferd Blood Stopper) application in deep tissue injuries in rats: histopathological investigation of the effect on regional and systemic tissues. Ulus Travma Acil Cerrahi Derg 2013;19:1-7.

23. Cancan G, Teksoz S, Aytac E, Arikan AE, Erman H, Uzun H, et al. Effects of Ankaferd on anastomotic healing of colon. J Invest Surg 2014;27:1-6. 